\title{
THE SOILS OF CENTRAL OTAGO
}

\author{
M. L. LEAMY \\ Pedologist, Soil Bureau, D.S.I.R. Alexandra
}

THE rocks and soils of Central Otago have fascinated men for more than 100 years, partly because they are such obvious features of an unusual landscape, but also because both have proved to be a source of wealth. The spectacular but short-lived harvest of gold served to open up the region to men who readily appreciated that the soils could be persuaded to yield much more than just this one, fickle, metallic crop. That their judgement was sound is indicated by the diverse and abundant agriculture flourishing in Central Otago today.

Central Otago is more a concept than a rigidly defined region, but for present purposes it is regarded as extending from the Southern Alps in the north-west to the Taieri Ridge and Lammerlaw Range in the south-east; and from the St. Bathans, Hawkdun and Kakanui Ranges in the north-east to Lake Wakatipu, the Carrick and Umbrella Mountains in the south-west. Thus defined, the region includes parts of Vincent, Maniototo, Lake, Tuapeka, Taieri and Waihemo Counties.

\section{The Soil Pattern}

The broad outline of the soil pattern of Central Otago is dictated by climatic differences which are unmatched elsewhere in New Zealand. Within less than 100 miles' distance, soils developed under rainfalls ranging from 13 in. to $150 \mathrm{in}$. occur, while soils formed under semi-arid conditions at an elevation of $500 \mathrm{ft}$ contrast strikingly with those developing a few miles away under alpine conditions at $6,000 \mathrm{ft}$. The wide distribution of parent materials derived from schist simplifies this pattern.

Brown-grey earths and related shallow and salty soils are confined to the driest districts where rainfall rarely exceeds 18 in. Where rainfall is greater than 18 in., but normally less than about 30 in., yellow-grey earths and re- 


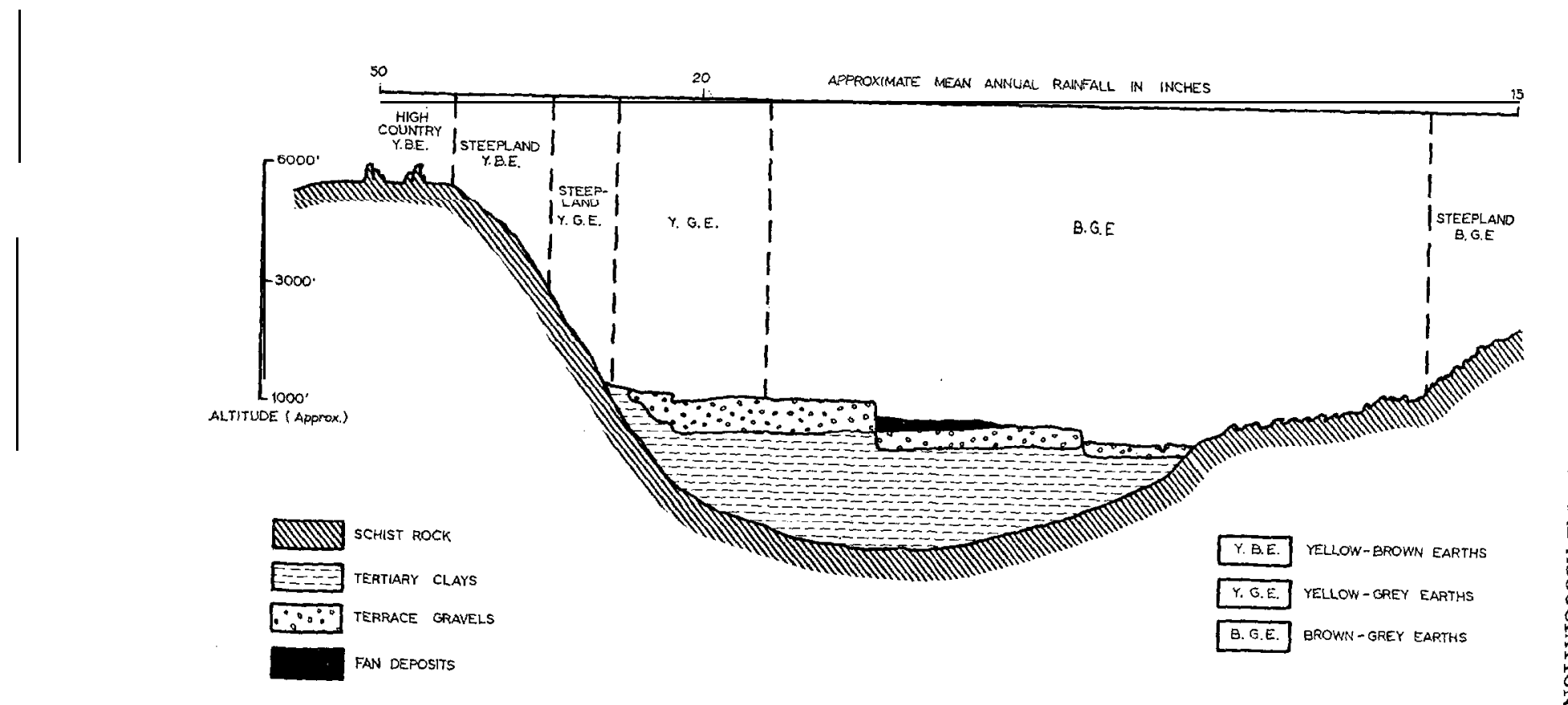

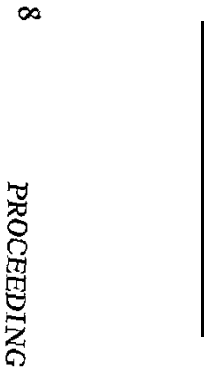

FIG. 1: Diagrammatic section across a typical segment of Central 0 tago showing geological structure, rainfall and soil sequences. 
lated shallow soils are formed; and, under higher rainfalls, yellow-brown earths and associated podzolized soils occur.

Central Otago is a mountainous region and the broad climatic and related soil changes also take place altitudinally. From the driest point, at Alexandra, it is possible to traverse these three main soil groups by travelling north, south, east, west or up.

Within this framework, the detailed soil pattern is closely related to those geological features which combine to form the characteristic range and basin terrain of Central Otago. The intermontane basins are partly infilled with fine grained lacustrine sediments of Tertiary age-commonly referred to as Tertiary clays-which in turn have been partly buried by Pleistocene alluvial gravels of mixed greywacke and schist composition, deposited by the main rivers as a series of spectacular terraces (McCraw, 1964; 1965). A nearly complete Pleistocene record is preserved in these terraces, many of which can be traced back to moraines in the vicinity of the lakes (McKellar, 1960; Leamy and Saunders, 1967). Fans of predominantly schist alluvium deposited by small streams descending from the mountains are widespread and important landscape features of the valley floors. Small outcrops of volcanic rocks occur in the north-eastern sector of Central Otago. Figure 1 illustrates the generalized geological structure, rainfall and soil sequences to be found in a typical segment of Central Otago.

\section{Soil Descriptions}

The soils of Central Otago may be divided into five main groups :

(1) Brown-grey earths and related salty, shallow and steepland soils of the driest parts of the inland basins and adjacent hills.

(2) Yellow-gvey earths and related shallow and steepland soils of the moister parts of the inland basins and adjacent hills.

(3) Yellow-brown earths and related podzolized, alpine, and steepland soils of the moist uplands and mountains.

(4) Brown granular loams and clays and related hill soils on small restricted outcrops of volcanic rocks. 
(5) Recent soils and associated gley recent soils of the floodplains and low terraces.

(1) Brown-Grey Earths

These soils are confined to the driest parts of Central Otago where the mean annual rainfall is less than $18 \mathrm{in}$. They are formed on basement schist or, more commonly, on colluvium, alluvium, loess or solifluction debris derived from schist; or on a mixture of these materials. They also occur on the greywacke-schist alluvium of the terraces associated with the main rivers.

Brown-grey earths have a weak biological regime consequent upon the marked moisture deficit of the environment, and this is expressed in the low humus content, the relatively sparse vegetation, weak topsoil structures, and very low density of soil animals (Lee, 1959 p. 426).

The distinctive features of brown-grey earth morphology are best expressed in strongly developed soils on mature land surfaces. These are:

(a) Weakly developed platy topsoil structures.

(b) Brown subsoil and grey topsoil colours.

(c) Claypan development in the subsoil.

(d) Accumulations of calcium carbonate and, in places, soluble salts in the deep subsoil.

The chemical credentials of the brown-grey earths are just as specific to the group as are the morphological features, and in general reflect the weak state of weathering and leaching-further manifestations of the semi-arid environment. In general brown-grey earth chemistry is characterized by :

(a) Slightly acid topsoils becoming increasingly alkaline with depth.

(b) Medium to high base saturation-an approximate measure of the amount of plant nutrients not removed by leaching-in the topsoil and increasing to very high levels with depth.

(c) Very low organic matter.

(d) High to very high available phosphate. 
(e) Very low phosphate retention (a measure of the soil's ability to render added phosphate unavailable) in the topsoil.

Almost all brown-grey earths contain soluble salts and in many places these become concentrated enough to dominate the profile morphology, modify or destroy the normal vegetation, and interfere with land use (McCraw, 1965 pp. 95-6).

Brown-grey earths on hills and steeplands are in general shallower, less well developed expressions of the same theme, although the low rainfall. does seem to reduce the mobility of soil material on steep slopes, and in some places subsoil clay and carbonate accumulation are quite conspicuous.

\section{(2) YelLow-Grey Earths}

In broad outline these soils occur in a position peripheral to the brown-grey earths, where the mean annual rainfall is greater than $18 \mathrm{in.}$ In some places they give way to yellow-brown earths where the mean annual rainfall is between 25 and 30 in., but elsewhere yellow-grey earths persist under rainfalls as high as 35 in.

Yellow-grey earths are best developed on deep, finegrained, schist-derived loess, alluvium or colluvium, and their salient morphological features are not well expressed in associated shallow soils formed on coarse alluvium.

Their biological regime is not as weak as is that of the brown-grey earths and this is reflected in the denser vegetation, the more strongly developed topsoil structures, the slightly higher humus content, and the markedly greater soil-animal activity (Lee, 1959 p. 427).

The diagnostic profile features which are best developed in deep soils on mature land surfaces are:

(a) Moderately developed nutty topsoil structures.

(b) Pale yellow subsoil and grey topsoil colours.

(c) A well-defined zone of earthworm activity between topsoil and subsoil.

(d) A compact subsoil pan with coarse prismatic structure. 
Chemically, the yellow-grey earths are approximately intermediate in most properties between the brown-grey earths and the yellow-brown earths. They have:

(a) Moderately to slightly acid topsoils changing little with depth.

(b) Medium to high base saturation levels in the topsoil decreasing only slightly with depth.

(c) A low organic matter level.

(d) Medium to low available phosphate levels.

(e) Low topsoil phosphate retention.

Many soils within the climatic zone where yellow-grey earths might be expected to develop are shallow, and do not exhibit the characteristic morphology as outlined above. They are formed on free-draining parent materials such as terrace or fan gravels and display affinities with the yellow-brown earths in the moister parts of the zone, and with the brown-grey earths in the drier parts. Similarly most steepland soils associated with yellow-grey earths do not exhibit a strong development of the yellow-grey earth morphology and are often regarded as steepland soils intermediate between brown-grey earths and yellowbrown earths.

\section{(3) YELLOW-Brown EARTHS}

Generally, where the mean annual rainfall exceeds about 30 in., yellow-brown earth features appear in the soils; and where mean annual rainfall is greater than $40 \mathrm{in}$. they are dominant. Yellow-brown earths are the most extensive soils in Central Otago and occur on the broad uplands, and on the mountains of the interior above about 3,000 ft. They are formed on schist, and on solifluction debris, loess, alluvium, colluvium and morainic detritus largely derived from schist.

Their biological regime is stronger than that of the other two groups and in general there is a well developed topsoil and subsoil fauna (Lee, 1959 p. 430), a dense tussock cover on virgin sites, a higher humus content, and weakly to moderately developed topsoil structures.

Prominent features of yellow-brown earth morphology are : 
(a) Brownish yellow subsoils and dark brown topsoils.

(b) Weakly to moderately developed crumb and granular structures in the topsoil.

(c) Friable consistencies throughout the soil.

(d) Blocky subsoil structures with not compaction and no development of pans.

Chemically, the yellow-brown earths tend to be more impoverished than the other two groups. They have:

(a) Strongly to moderately acid topsoils changing little with depth.

(b) Medium base saturation levels decreasing dramatically to low and very low levels in subsoils.

(c) A low level of organic matter.

(d) Low and very low values for available phosphate.

(e) Low to medium topsoil phosphate retention (Saunders, 1965).

Above about 4,500 $\mathrm{ft}$ on the broad, rolling summits of the interior mountain ranges, high country yellow-brown earths are shallow and coarse textured as would be expected under increasingly alpine conditions. Above about $6,000 \mathrm{ft}$ in the western mountains, alpine steepland soils, consisting of little more than bare rock and scree, are recognized. Podzolized yellow-brown earths occur mainly west of the lakes under high rainfalls but at moderate elevations, and are characterized by thick, slightly peaty topsoils separated from strong brown subsoils by a palecoloured eluvial A horizon.

Steepland yellow-brown earths have similar properties to the yellow-brown earths of the rolling uplands but are shallower, have abundant fragments of unweathered rock throughout, and are more easily eroded.

Figure 2 shows the main morphological features of the three main groups described above.

\section{(4) Brown Granular loams and Clays}

There are only small areas of these soils and they occur in association with brown-grey earths and yellow-grey earths in the northern parts 'of the Maniototo basin and the Strath Taieri depression. They are formed on a dis- 


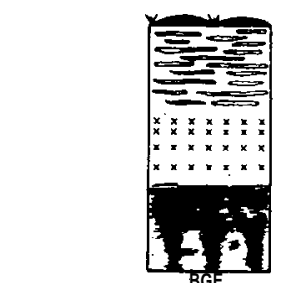

KEY TO SYMBOLS

VEGETATION

Low tuseock

Tall tussoek

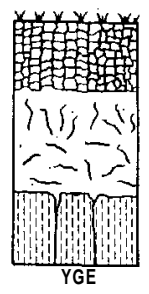

Soll

Ploty structure

Claypon

Carbanate accumulation

Nutty structure

Earthrom . mixing
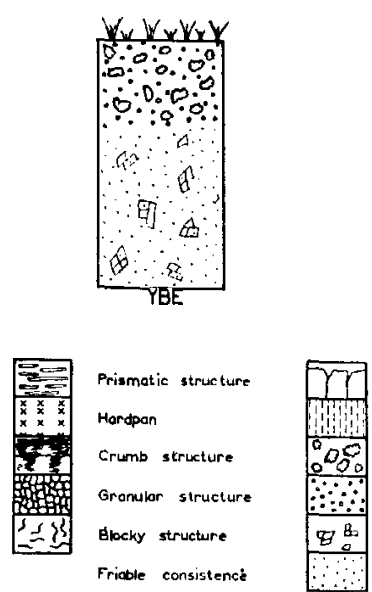

FIG. 2: Idealized diagrams of profiles representing the three main soil groups of Central 0 tago.

sected basalt sheet overlying Tertiary clays and silts and in most places form a complex pattern with soils developed on the Tertiary sediments (Raeside et al., $1966 \mathrm{p}$. 43). The basalt soils are shallow, stony and droughty and contain a high proportion of unweathered primary minerals.

\section{(5) RECENT SOILS}

These soils occur throughout Central Otago on alluvium that has been deposited in the recent past or is still being deposited by floods. They are characterized by weakly differentiated profiles with textures ranging from silt to gravel, dependent upon the texture of the alluvium. Re lated gley recent soils, showing evidence of waterlogging, are common in poorly drained locations; and in some places in the brown-grey earth zone recent soils are salty.

\section{Soil Properties Significant to Grassland Farming}

Prior to European settlement, most of Central Otago supported tussock grassland vegetation. The early settlers brought with them an agricultural tradition which was based largely on experience with the leached, formerly forested soils of northern Europe. The clash of this tradi- 
tion with a different set of soil conditions left its impact on the soils, and many of Central Otago's pastoral problems are legacies of the cultural adjustment which has taken place over the last 100 years.

In the brown-grey earth zone it was recognized early that moisture deficiency was a limitation to pastoral farming, but because the zone is of limited extent and be cause the correction of nutrient deficiencies had produced such spectacular results elsewhere in N ew Zealand, it was perhaps not appreciated, nationally at least, what an overwhelming limitation inadequate rainfall was. Thus irrigation grassland farming tended to evolve more as an extension of our humid zone agriculture, rather than as a distinct, technically demanding, farming system. While the nutrient requirements of grasses were, in the main, adequately catered for, insufficient attention was paid to the more specific demands of irrigation farming. For example, irrigation requires special soil conditions, such as good permeability; all soils are not equally suitable for irrigation; and irrigation and drainage must often go hand in hand. Such oversights have been recognized in recent years, but many acres of partially waterlogged and salt-contaminated soils remain in the brown-grey earth zone as evidence of an incomplete adjustment to browngrey earth agriculture.

Early agricultural practices in Central Otago were not exclusively pastoral, and to some extent this is still true. In the yellow-grey earth zone where deep soils under a subhumid climate are in many respects ideal for cropping, early enthusiasm in some places caused good husbandry to be abandoned temporarily and overcropping led to soil deterioration. On the deep soils of the Crown Terrace, near Queenstown, it is said that the settlers went from shirtsleeves to shirtsleeves in three generations-the first generation worked in shirtsleeves to develop their farms; the second generation enjoyed the temporary benefits of continuous cropping without having to take off their coats; and the third generation were back to shirtsleeves trying to wrest a living from the exhausted and eroding soils. On the yellow-grey earths of the Wanaka district, the effects of 60 years of continuous cropping were still being felt as recently as 10 years ago when sheep were afflicted with a crippling malady, eventually identified as selenium 
deficiency. This was a soil deficiency probably induced by previous management practices (Leamy and Schofield, 1960). In both these instances modern grassland farming techniques are ameliorating the degraded soils.

A mong the friable soils of the yellow-brown earth zone a conflict developed between soil conservation and sheep grazing. The fact that burning of the thick tussock cover would provide access and temporary grazing for sheep obscured the insidious degeneration of the vegetation and the consequent erosion of the friable soils. It is almost impossible today to find uneroded yellow-brown earths on hilly and steep land in Central Otago (McCraw, 1965 p. 100). Impressive progress in alleviating this problem at lower altitudes has been made in recent years by the use of fertilizer and species adapted to the environment, but its complete and permanent solution requires a reorientation of high country farming tradition to such modern research advances.

It is not difficult to pinpoint these situations with hindsight, but what is more important is to recognize the lesson-that pastoral farming in Central Otago must become fully adapted to soil and other environmental conditions. Physically, differences in the moisture regime and erodibility of the three main soil groups must be taken into account. Current research by government departments and local bodies is aimed to achieve this. Chemically, an outstanding correlation between the broad features of the three main groups and pasture responses has been demonstrated already by Department of Agriculture trials. The increasing response to several nutrients through the sequence brown-grey earths $\longrightarrow$ yellow-grey earths $\longrightarrow$ yellow-brown earths (Ludecke, 1960; 1966) is now partly predictable from a knowledge of the pedological characteristics and the basic chemistry and is probably related to the increasing leaching under a progressively heavier rainfall.

\section{Soil Classification for Pastoral Use}

A broad picture of the factors limiting the pastoral use of Central Otago soils may be obtained by referring them to a classification devised by Gibbs (1963). In this scheme soils of the flat and rolling lands are separated from those on hilly and steep lands, and both groups are sub- 
divided according to the severity of limitations. Central Otago soils fall into four limitation categories, corresponding to Classes 2, 3, 5, and 6 of Gibbs' classification:

Class 2: Soils of the flat and rolling lands with moderate soil limitations to pastoral production and use.

Included in this class are the recent soils, most of which have limitations of coarse texture or insufficient moisture, the yellow-grey earths, which have insufficient moisture, and, to a lesser extent, nutrients, and the yellow-brown earths which have limitations of elevation, erodibility and nutrients.

Class 3: Soils of the flat and rolling lands with severe soil limitations to pastoral production and use.

Brown-grey earths and brown granular loams and clays, which have the limitation of frequent dryness, are placed in this group.

Class 5: Soils of hilly and steep lands with moderate to severe soil limitations to pastoral production and use.

Hilly and steepland yellow-grey earths are included here because of insufficient moisture; and moderate erosion limitations place hilly yellow-brown earths in this class.

Class 6: Soils of hilly and steep lands with severe to very severe soil limitations to pastoral production and use.

Hilly and steepland brown-grey earths are included here because they are subject to frequent dryness and are also susceptible to erosion. Steepland yellow-brown earths and alpine steepland soils are placed here because of the limitation of rapid erosion.

A classification such as this clearly outlines the limitations and should ensure that no serious errors are made in land development. However, it does not set out to provide a realistic assessment of ultimate soil potential, and it is a fact that some of the highest producing soils in Central Otago-irrigated brown-grey earths on flat landhave severe soil limitations in the unimproved state and fall into Class 3. There are other methods of assessing soil capability to show differences in potential production between various soils after the application of obvious corrective measures, and one such method has been applied to a small area of Central Otago for which detailed soil information is available (Leamy, 1962). This system 
is not at present more generally applicable because it requires further experimental testing and also because it requires more detailed soil data than are available over a wide area.

\section{REFERENCES}

Gibbs, H. S., 1963: Soils of New Zealand and their limitations for pastoral use. Proc. N.L, Inst. agri. Sci., 63-79.

Leamy, M; Schofield, R. C. 1960: Problems of development in the Wanaka district. Proc. N.Z. Inst. agri. Sci., 60-3.

Leamy, M. L., 1962: The correlation of soil classification and soil capability in the Upper Clutha Valley, Otago, New Zealand. l'runs. Joint $M$ tg. Comm. IV d' V Int. Soc. Soil Sci., 749-54.

Leamy, M. L.; Saunders W. M. H. 1967: Soils and land use in the Upper Clutha Valley, Otago. N.Z. Soil Bur. Bull. 28.

Lee, K. E., 1959: The earthworm fauna of New Zealand. N.Z. Dept. Sci. ind. Res, Bull. 130.

Ludecke, 'í'. E., 1900: Improvement of iow altitude tussock country in Central Otago. Proc. N.Z. Grassl. A ss., 96-110.

1966: The use of soil sequences in formulating a fertilizer programme when introducing legumes mto tussock country in New Lealand. Proc. Int. Grassl. Cont., Helsinki (in press).

McCraw, J. D., 1964: Soils of Alexandra district. N.Z. Soil Bur. Bull. 24. 1965: Central Otago: Soils and conservation. Special Pub., N.L. Geographical Soc. ivisc. Series N 0. 5., 92-102.

McKellar, 1. C., 1960: Pleistocene deposits of the Upper Clutha Valley, Otago, New Zealand. N.L. 1. Geol. Lieophys, 3:452-60.

Raeside, J. D.; Cutler, E. J. B.; Miller, R. B., 1960: Soils and related irrigation problems of part of Maniototo Plains, Otago, N.Z. Soil Bur. Bull. 23.

Saunders, W. M. H., 1965: Phosphate retention by New Zealand soils and its relationship to free sesquioxides, organic matter and other soil properties. N.L. J. ngri. Res., 8: (1) 30-57.

\section{DISCUSSION}

Could M r Leamy give more information on the phosphate retention of the high country yellow-brown earths, which could be similar to that of the pumice soils of the $\mathrm{N}$ orth Island?

Saunders (1965) is my source of information for phosphate retention values. He quotes 35 as the mean value for high country yellow-brown earths, with a value of 43 for steepland high country yellow-brown earths. This compares with values of 9 for prown-grey earths, 20 for yellow-grey earths, 48 for yellow-brown pumice soils and 93 for yellowbrown loams. Recent work has suggested that a significant amount of amorphous colloidal material with high phosphate retention characteristics does appear in soils whose environment or history includes intensive comminution and physical weathering generally, and this would apply to the high country yellow-brown earths. This in fact is probably the explanation of the quite marked difference in phosphate retention between yellow-grey earths and high country yellow-brown earths. 


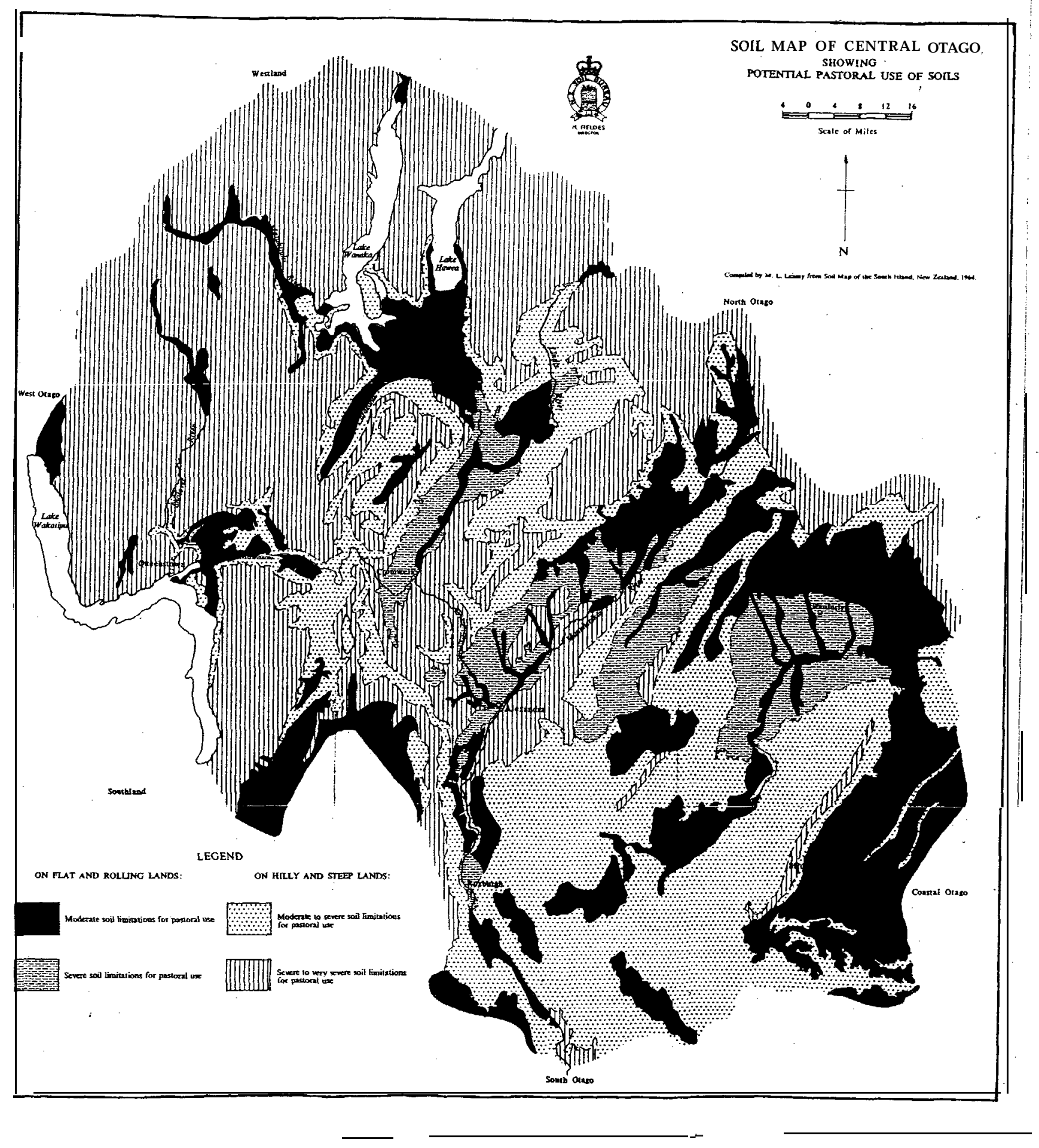




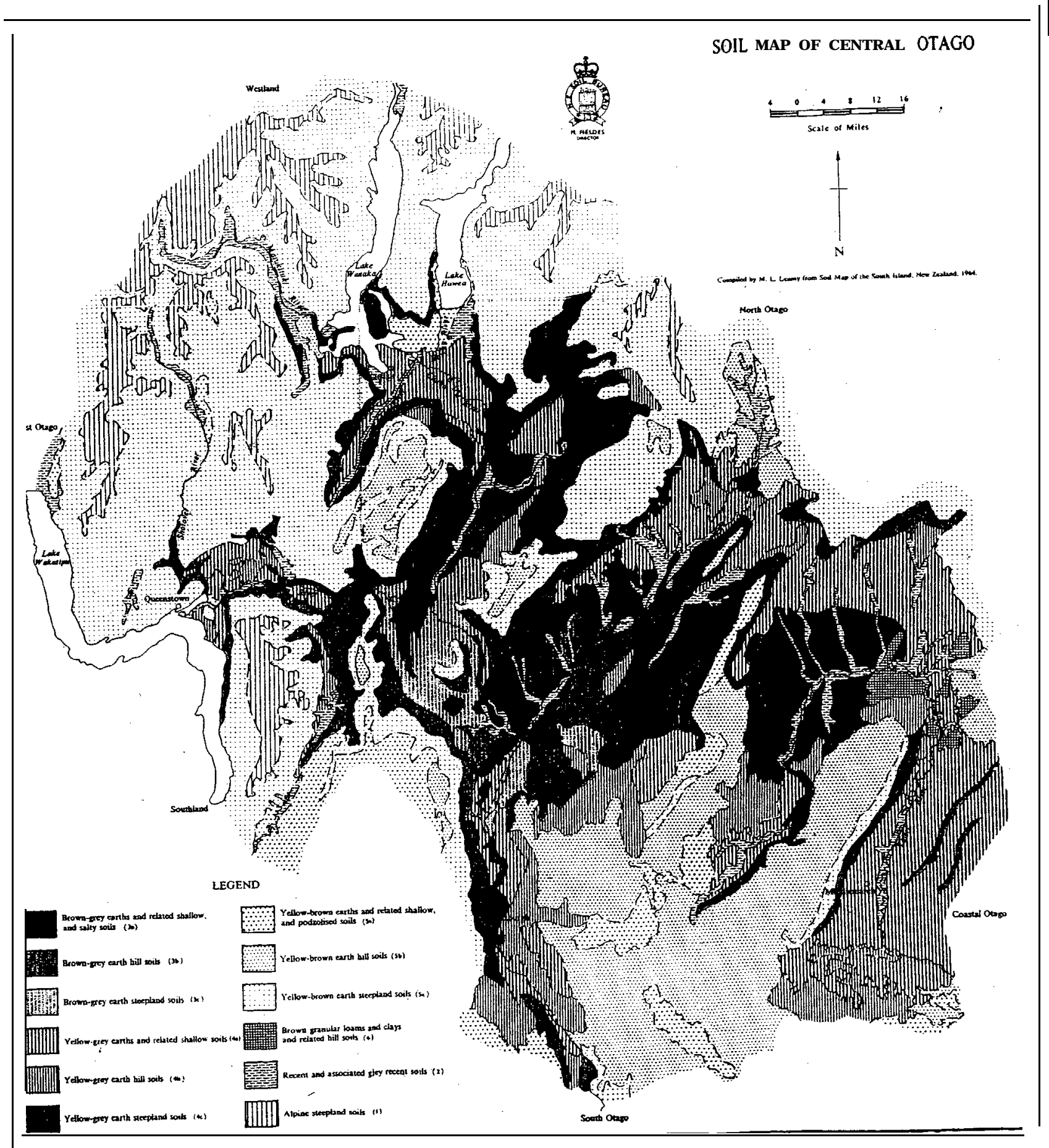

